\title{
Growth, Yield and Quality Parameters of Cucumber (Cucumis sativus L.) as Influenced by Integrated Nutrient Management Application
}

\author{
Jagraj Singh*, Manoj Kumar Singh, Mukesh Kumar, \\ Archi Gupta and Kaushelendra Pratap Singh \\ Department of Horticulture, S. V.P. University of Agriculture \& Technology, \\ Meerut (U.P.), India \\ *Corresponding author
}

\section{A B S T R A C T}

\begin{tabular}{l} 
K e y w o r d s \\
Cucumber, INM, \\
NPK, FYM, \\
Vermicompost, \\
Growth, Yield and \\
Quality \\
\hline Article Info \\
$\begin{array}{l}\text { Accepted: } \\
\text { 12 September } 2020 \\
\text { Available Online: } \\
\text { 10 October } 2020\end{array}$ \\
\hline
\end{tabular}

Keywords

Cucumber, INM, NPK, FYM,

Vermicompost, Growth, Yield and

\section{Introduction}

Vegetables play an important role to keep human beings healthy. Vegetables have a great significance in providing food and nutritional security and as well as provides regular income to vegetable grower. Vegetables are important constituents of Indian diets as they are rich source of carbohydrates, proteins, vitamins, minerals, glucosinolates, antioxidants and fibers (Singh et al., 2016). Vegetable provides various

\begin{abstract}
The present study was carried out at Horticulture Research Centre of Sardar Vallabhbhai Patel University of Agriculture and Technology, Meerut during 2018. Total ten treatments were tried in Randomized Block Design (RBD) with three replications to study the effect of integrated nutrient management on growth, yield and quality of Cucumber. Out of these, an application of $75 \% \mathrm{RDF}+12.5 \% \mathrm{FYM}+12.5 \% \mathrm{VCha}^{-1}$ was found significantly superior in terms of growth, yield and quality parameters i.e. vine length $(\mathrm{cm})$, number of leaves plant ${ }^{-1}$, number of primary branches plant ${ }^{-1}$, length and width of leaf $(\mathrm{cm})$, days taken to first fruit formation (days), number of fruits plant ${ }^{-1}$, length and width of fruit at edible maturity $(\mathrm{cm})$, weight of fruit at edible maturity $(\mathrm{g})$, fruit yield plant $^{-1}(\mathrm{~kg})$, fruit yield $\operatorname{plot}^{-1}(\mathrm{~kg})$, total fruit yield $\left(\mathrm{qha}^{-1}\right)$, TSS $\left({ }^{0}\right.$ Brix)and peel thickness $(\mathrm{cm})$ as compared to control and other applied treatment. Overall the impact of above observation, the highest yield $\left(148.88 \mathrm{qha}^{-1}\right)$ of green tender fruits was recorded with a combined dose of different organic and inorganic sources of nutrients like $75 \% \mathrm{RDF}+12.5 \% \mathrm{FYM}+12.5 \% \mathrm{VCha}^{-1}$ and minimum yield (93.33 $\left.\mathrm{qha}^{-1}\right)$ of green tender fruits was observed under control.
\end{abstract}

essential heath nutrients as above and said that "Vegetables are friends of doctors and glory of cook". These are essential commodities to human diet particularly in India as large sections of people are vegetarian. Cucumber (Cucumis sativus L.) is extensively grown vegetable crop of cucurbitaceae family. The chromosome numbers of cucumber are $2 \mathrm{n}=14$ (De, Candole, 1999). Cucumber is second most widely cultivated cucurbitaceous crop in world after watermelon. Cucumber is 
creeping vine that can reach upwards up to 90 $\mathrm{cm}$ in length. The spiraling hairy vine and tendrils that originate from the axils, allow the plant to readily climb on supporting structures. The overall root system is generally shallow with lateral roots extending further than the vine. However, a tap root can reach one meter deep. It is a cross pollinated crop and is pollinated by bees. The cucumber plant produces three types of rough yellow flowers including a male or staminate flower, a female or pistillate flower and a hermaphrodite flower with both male and female structures. The pistillate flower can be recognized from its thin pedicles and it has a large ovary (immature fruit) at its base. The staminate flower grows in clusters and each flower is on a slender stem having three stamens. Hermaphroditic flowers are able to produce round fruits. Regardless of the sex, the flowers are yellow with wrinkled petals. The ovary has three chambers and is connected to short, thick stigma lobes. It is a warm season crop and susceptible to frost. Optimum temperature range for the growth and development of cucumber is $18^{\circ} \mathrm{C}-24^{\circ} \mathrm{C}$. A well-drained loamy soil is preferred for cucumber cultivation with $\mathrm{pH}$ ranges 6.0 to 7.0. Cucumber is a very good source of vitamins $\mathrm{A}, \mathrm{C}, \mathrm{K}, \mathrm{B}_{6}$, potassium, pantothenic acid, magnesium, phosphorus, copper and manganese (Vimala et al., 1999). Edible portion of cucumber contains $0.4 \%$ protein, $2.5 \%$ carbohydrates and $0.1 \%$ fat and $7.0 \mathrm{mg}$ vitamin C, $25 \mathrm{mg}$ phosphorus, $10 \mathrm{mg}$ calcium and $1.5 \mathrm{mg}$ iron per $100 \mathrm{~g}$ edible fruit. It is used for fresh consumption (slicing cucumber) and for preservation. Immature fruits are universally used as salad, pickling and also used with curd for the preparation of "Rayata". The green leaves are used as potherbs and seeds and seed oils are also edible (Hazra et al., 2011). Integrated Nutrient Management (INM) system refers to the balanced use of chemical fertilizers in combination with organic manures, crop residues, biofertilizers and other biological sources (Thriveni et al., 2015). Organic manures increase the organic matter in the soil. They provide organic acids that help dissolve soil nutrients and make them available for the plants. An application of organic manures improves the soil fertility, soil structure and water holding capacity. Integrated Nutrient Management is one of the recent methods of supplying nutrients to the plants by organic as well as inorganic sources of nutrients to fulfill the nutrient requirements. The main aim of Integrated Nutrient Management is to minimize the use of chemical fertilizers without immolate the yield. FYM and vermicompost are bulky organic manures, although supply low quality of major nutrients, but have potential to supply all essential nutrients for longer periods (Baghel et al., 2017). Nitrogen is a key nutrient which promotes vegetative growth, developments and yield of fruit. Nitrogen plays a central role in the synthesis of chlorophyll and essential constituent of compounds like amino acid, proteins, nucleic acids, porphyrin, flavin, pyridines, nucleotides, enzymes, coenzymes and alkaloids which contributes to the growth of plant. Phosphorous play an important role in the production of vegetable crops, it imparts hardiness to shoot, increased size of fruit and quality, regulates the photosynthesis, governs physic-bio-chemical processes and helps root enlargement. Potassium is necessary for many functions of plants like carbohydrate metabolism, enzyme activation, osmotic regulation and efficient use of water, nitrogen uptake and protein synthesis and translocation of assimilates. It also has a role in decreasing certain plant diseases and improves fruit quality of vegetables (Singh, 1991).

\section{Materials and Methods}

A field experiment was conducted at Horticultural Research Centre, Sardar 
Vallabhbhai Patel University of Agriculture and Technology, Meerut (U.P.) 250110 during the summer season of year 2018. The experiment was laid out in Randomized Block Design (RBD) and replicated thrice. Total ten treatments were tried namely $\mathrm{T}_{1}-\mathrm{RDF}$ (100:60:60 NPK ha $\left.{ }^{-1}\right), \mathrm{T}_{2}-\mathrm{RDF}+15$ tonnes $\mathrm{FYM}, \mathrm{T}_{3}-\mathrm{RDF}+10$ tonnes $\mathrm{VC}, \mathrm{T}_{4}-75 \%$ $\mathrm{RDF}+25 \% \mathrm{FYM}, \mathrm{T}_{5}-75 \% \mathrm{RDF}+25 \%$ $\mathrm{VC}, \mathrm{T}_{6}-50 \% \mathrm{RDF}+50 \% \mathrm{FYM}, \mathrm{T}_{7}-50 \%$ $\mathrm{RDF}+50 \% \mathrm{VC}, \mathrm{T}_{8}-75 \% \mathrm{RDF}+12.5 \%$ $\mathrm{FYM}+12.5 \%$ VC, $\mathrm{T}_{9}-50 \% \mathrm{RDF}+25 \%$ $\mathrm{FYM}+25 \% \mathrm{VC}$ and $\mathrm{T}_{10}-$ Control. The soil of the experimental field was sandy loam in texture having $\mathrm{pH}$ of 7.70 with available nitrogen $\left(149.80 \quad \mathrm{~kg} \mathrm{ha}^{-1}\right), \quad$ available phosphorus $\left(24.18 \mathrm{~kg} \mathrm{ha}^{-1}\right)$ and available potassium (113 $\left.\mathrm{kg} \mathrm{ha}^{-1}\right)$. The cucumber variety Pant Khira-1 was taken for study purpose. It was earlier evolved through inbreeds of indigenous germplasm at pantnagar and released by the G. B. Pant University of Agriculture \& Technology, Pantnagar (Uttarakhand) in 2001 and recommended for western Uttar Pradesh and Uttarakhand for commercial cultivation. The seeds were sown in field at a spacing of 1.50 $\mathrm{m} \times 0.60 \mathrm{~m}$. The organic manure like FYM was incorporated in experimental field as per the treatments suggested prior to two week of seed sowing. However, the vermicompost was also applied in experimental plots at the time of sowing. The nitrogen, phosphorus and potassium were applied in the form of urea, single super phosphate (SSP) and muriate of potash (MOP). The half dose of nitrogen, full dose of phosphorus and potassium were applied in experimental plots at the time of seed sowing. The remaining half dose of nitrogen was applied in two equal doses at vining stage and flower initiation stage. All the cultural practices were done at regular intervals with the requirement of crop during the course of investigation. Similarly, plant protection measures were also done with spraying fungicides and insecticides like mancozeb and monocrotophos. During the experimentation, various observations on growth yield and yield promoting parameters with their quality were recorded during whole of the cropping period. Thereafter, data were recorded from three randomly selected plants in each treatment and statically analyzed by RBD at $5 \%$ level of significance using statistical method as suggested by Gomez and Gomez (1996).

\section{Results and Discussion}

\section{Growth parameters}

Growth parameters like vine length, number of leaves, number of primary branches, length and width of leaf in cucumber were significantly affected by various INM doses of organic manure and fertilizers during the crop growth period in cucumber as shown in (Table 1). The highest vine length (137.70 $\mathrm{cm})$, maximum number of leaves plant $^{-1}$ (97.80), more number of primary branches plant $^{-1}(8.50)$ was recorded with the treatment $\mathrm{T}_{8}(75 \% \mathrm{RDF}+12.5 \% \mathrm{FYM}+12.5 \% \mathrm{VC}$ ha ${ }^{1)}$ followed by $\mathrm{T}_{3}-\mathrm{RDF}+10$ tones $\mathrm{VC} \mathrm{ha}^{-1}$, while the lowest vine length $(119.80 \mathrm{~cm})$, minimum numbers of leaves plant ${ }^{-1}$ (77.80) and lowest number of primary branches plant $^{-1}(3.90)$ was found in control $\left(\mathrm{T}_{10}\right)$. This may be due to improved nutrient uptake by plants in this treatment, resulting improved vegetative growth. The organic manure applied in the form of FYM and vermicompost might have improved the physical and chemical properties of the soil and leading to the adequate supply of nutrients to the plants with sufficient water holding capacity and might have accelerate the vine length, number of leaves plant ${ }^{-1}$ and number of primary branches plant $^{-1}$. The combined application of FYM, vermicompost and inorganic fertilizers increased the absorption of nutrients especially nitrogen which enhanced the cell division, cell 
elongation and increased the plant growth. These findings are in line with Mahmoud et al., (2009), Vishwakarma et al., (2007) and kumar and Karuppaih (2008). The treatments the maximum length $(16.20 \mathrm{~cm})$ and width of leaf $(16.70 \mathrm{~cm})$ was found in treatment like $75 \% \mathrm{RDF}+12.5 \% \mathrm{FYM}+12.5 \% \mathrm{VC} \mathrm{ha}^{-1}$ followed by $\mathrm{RDF}+10$ tones $\mathrm{VC} \mathrm{ha}{ }^{-1}$. However, the control plants had the lowest length of leaf $(9.50 \mathrm{~cm})$ and width of leaf $(11.00 \mathrm{~cm})$. The significant increase in length and width of leaf might be due to better nutrient supply by specific combination of INM treatments which leads to increase the internal metabolic activities in plants. The similar results were also reported by Kumar and Karuppaiah (2008), Prasad et al., (2009), Anjanappa et al., (2012).

Table.1 Effect of integrated nutrient management on growth parameters of cucumber

\begin{tabular}{|c|c|c|c|c|c|}
\hline Treatments & $\begin{array}{c}\text { Vine length } \\
\text { (cm) }\end{array}$ & $\begin{array}{c}\text { No. of leaves } \\
\text { plant }^{-1}\end{array}$ & $\begin{array}{c}\text { No. of Branches } \\
\text { plant }^{-1}\end{array}$ & $\begin{array}{c}\text { Leaf length } \\
(\mathbf{c m})\end{array}$ & $\begin{array}{c}\text { Leaf width } \\
(\mathbf{c m})\end{array}$ \\
\hline $\mathbf{T}_{\mathbf{1}}$ & 129.50 & 87.70 & 6.60 & 14.00 & 14.40 \\
\hline $\mathbf{T}_{\mathbf{2}}$ & 131.70 & 91.20 & 7.50 & 14.50 & 15.40 \\
\hline $\mathbf{T}_{\mathbf{3}}$ & 134.10 & 94.00 & 7.90 & 15.30 & 16.10 \\
\hline $\mathbf{T}_{\mathbf{4}}$ & 126.00 & 83.90 & 6.00 & 13.00 & 13.10 \\
\hline $\mathbf{T}_{\mathbf{5}}$ & 127.60 & 86.10 & 6.40 & 13.50 & 13.70 \\
\hline $\mathbf{T}_{\mathbf{6}}$ & 122.40 & 81.00 & 4.30 & 11.60 & 12.00 \\
\hline $\mathbf{T}_{\mathbf{7}}$ & 124.40 & 82.70 & 5.20 & 12.40 & 12.30 \\
\hline $\mathbf{T}_{\mathbf{8}}$ & 137.70 & 97.80 & 8.50 & 16.20 & 16.70 \\
\hline $\mathbf{T}_{\mathbf{9}}$ & 133.40 & 93.20 & 7.70 & 14.80 & 15.90 \\
\hline $\mathbf{T}_{\mathbf{1 0}}$ & 119.80 & 77.80 & 3.90 & 9.50 & 11.00 \\
\hline S.Em & $\mathbf{0 . 3 1}$ & $\mathbf{0 . 4 0}$ & $\mathbf{0 . 2 6}$ & $\mathbf{0 . 3 4}$ & $\mathbf{0 . 2 5}$ \\
\hline C. $\mathbf{D}$ & $\mathbf{0 . 8 9}$ & $\mathbf{1 . 1 6}$ & $\mathbf{0 . 7 5}$ & $\mathbf{1 . 0 0}$ & $\mathbf{0 . 7 2}$ \\
\hline
\end{tabular}

Table.2 Effect of integrated nutrient management on yield and quality parameters of cucumber

\begin{tabular}{|c|c|c|c|c|c|c|c|c|c|c|}
\hline Treatments & $\begin{array}{l}\text { Days taken } \\
\text { to } 1^{\text {st }} \text { fruit } \\
\text { formation } \\
\text { (Days) }\end{array}$ & $\begin{array}{l}\text { No. of } \\
\text { fruits }^{-1} \\
\text { plant }^{-1}\end{array}$ & $\begin{array}{c}\text { Fruit } \\
\text { length } \\
\text { (cm) }\end{array}$ & $\begin{array}{c}\text { Fruit } \\
\text { Widt } \\
\text { h } \\
(\mathbf{c m})\end{array}$ & $\begin{array}{c}\text { Weigh } \\
t \text { of } \\
\text { fruit } \\
(\mathrm{g})\end{array}$ & $\begin{array}{c}\text { Fruit } \\
\text { yield } \\
(\mathbf{k g} \\
\left.\text { plant }^{-1}\right)\end{array}$ & $\begin{array}{c}\text { Fruit } \\
\text { yield } \\
\left(\begin{array}{c}\text { kg plot } \\
\text { 1) }\end{array}\right.\end{array}$ & $\begin{array}{c}\text { Fruit } \\
\text { yield }(\mathbf{q} \\
\left.\text { ha }^{-1}\right)\end{array}$ & $\begin{array}{c}\text { TSS } \\
\left({ }^{0} \mathrm{Bri}\right. \\
\mathbf{x})\end{array}$ & $\begin{array}{c}\text { Peel } \\
\text { thickn } \\
\text { ess } \\
(\mathrm{cm}) \\
\end{array}$ \\
\hline$T_{1}$ & 56.30 & 7.40 & 17.50 & 3.59 & 152.90 & 1.13 & 6.78 & 125.55 & 3.52 & 0.91 \\
\hline $\mathbf{T}_{2}$ & 60.57 & 7.60 & 17.50 & 3.83 & 154.60 & 1.14 & 6.84 & 126.66 & 3.70 & 0.96 \\
\hline $\mathbf{T}_{3}$ & 55.96 & 8.30 & 19.30 & 4.31 & 159.90 & 1.27 & 7.62 & 141.11 & 3.94 & 1.11 \\
\hline $\mathbf{T}_{4}$ & 65.17 & 7.20 & 15.40 & 3.08 & 149.80 & 1.06 & 6.36 & 117.77 & 3.02 & 0.76 \\
\hline$T_{5}$ & 62.03 & 7.30 & 16.60 & 3.39 & 151.50 & 1.11 & 6.66 & 123.33 & 3.38 & 0.87 \\
\hline$T_{6}$ & 69.07 & 6.90 & 13.60 & 2.67 & 145.30 & 1.01 & 6.06 & 112.22 & 2.42 & 0.68 \\
\hline $\mathbf{T}_{7}$ & 67.17 & 7.00 & 14.30 & 2.91 & 147.40 & 1.05 & 6.30 & 116.66 & 2.79 & 0.71 \\
\hline$T_{8}$ & 53.40 & 8.35 & 20.20 & 4.38 & 161.50 & 1.34 & 8.04 & 148.88 & 4.11 & 1.33 \\
\hline$T_{9}$ & 57.97 & 7.90 & 18.60 & 4.03 & 156.40 & 1.24 & 7.44 & 137.70 & 3.81 & 1.01 \\
\hline$T_{10}$ & 72.23 & 6.10 & 11.10 & 2.57 & 137.80 & 0.84 & 5.04 & 93.33 & 1.74 & 0.47 \\
\hline S.Em & 0.46 & 0.19 & 0.38 & 0.15 & 0.49 & 0.03 & 0.21 & 2.70 & 0.06 & 0.05 \\
\hline C. D. & 1.33 & 0.54 & 1.08 & 0.42 & 1.43 & 0.08 & 0.61 & 7.81 & 0.18 & 0.13 \\
\hline
\end{tabular}




\section{Yield parameters}

Yield and yield attributing characters like days taken to first fruit formation, number of fruits plant ${ }^{-1}$, length of fruit $(\mathrm{cm})$, width of fruits $(\mathrm{cm})$, weight of fruit at edible maturity $(\mathrm{g})$, fruit yield plant $^{-1}(\mathrm{~kg})$, fruit yield plot $^{-1}$ $(\mathrm{kg})$ and total fruit yield $\left(\mathrm{q} \mathrm{ha} \mathrm{h}^{-1}\right)$ were found statistically differed among the treatment applied in integrated manner i.e. organic and inorganic with or without combination during the course of investigation. (Table. 2)

The minimum days to first fruit initiation (53.40) were recorded in $\mathrm{T}_{8}-75 \% \mathrm{RDF}+$ $12.5 \% \mathrm{FYM}+12.5 \% \mathrm{VC} \mathrm{ha}^{-1}$ followed by $\mathrm{T}_{3}$ - RDF +10 tones $\mathrm{VC} \mathrm{ha}{ }^{-1}$, while maximum days to first fruit initiation (72.23) were noted under $\mathrm{T}_{10}$ (control). The integrated approach of nutrient application has improved earliness fruiting as compared to unfertilized plot. These findings are in line with Arshad et al., (2014) and Moharana et al., (2017).

The maximum number of fruits plant ${ }^{-1}(8.40)$, maximum length of fruit $(20.20 \mathrm{~cm})$, highest fruit width $(4.38 \mathrm{~cm})$ and maximum weight of edible fruit $(161.50 \mathrm{~g})$ were recorded with combination of $75 \% \mathrm{RDF}+12.5 \% \mathrm{FYM}+$ $12.5 \% \mathrm{VC} \mathrm{ha}^{-1}$ followed by $\mathrm{T}_{3}-\mathrm{RDF}+10$ tones $\mathrm{VC} \mathrm{ha}{ }^{-1}$. Whereas, minimum number of fruits plant ${ }^{-1}(6.10)$, lowest fruit length (11.10 $\mathrm{cm})$ and width $(2.57 \mathrm{~cm})$ and minimum weight of edible fruit $(137.80 \mathrm{~g})$ were observed under control. This is because of more length and axillaries branches which maximized the fruiting buds on a vine and ultimately number of fruits plant ${ }^{-1}$ was increased. The number of fruits plant ${ }^{-1}$ significantly increased with incremental uses of inorganic nutrients and further with integrated uses of FYM and vermicompost. The progressive increase in number of fruits plant $^{-1}$ might be due to the integrated use of organic manures and chemical fertilizers like nitrogen, phosphorous and potassium application through organic manures might have accelerated the synthesis of chlorophyll and amino acids resulting more translocation of photosynthesis from leaves to fruits caused increased number of fruits plant ${ }^{-1}$. Similar findings are in conformity with the findings of Eifediyi and Remison (2010) and Mohrana et al., (2017). Increase in length and width of fruit and weight of edible fruit might be due to, phosphorous content of plant tissue, which results in proper formation of nucleic acids and due to cell division average fruit weight might have increased. In addition, organic manures are slow releaser and provide nutrients throughout growth period. These findings are also in consonance with the findings of Arisha et al., (2003), Arshad et al., (2014) and Singh et al., (2017).

An application of $75 \% \mathrm{RDF}+12.5 \% \mathrm{FYM}+$ $12.5 \% \mathrm{VC} \mathrm{ha}^{-1}$ gave highest fruit yield plant ${ }^{-1}$ $(1.34 \mathrm{~kg})$, fruit yield $\operatorname{plot}^{-1}(8.04 \mathrm{~kg})$ and total fruit yield $\left(148.8 \mathrm{q} \mathrm{ha}^{-1}\right)$. Whereas, in case of control plant had lowest fruit yield plant ${ }^{-1}(0.84$ $\mathrm{kg})$ and fruit yield $\operatorname{plot}^{-1}(5.04 \mathrm{~kg})$ and minimum fruit yield $\left(93.33 \mathrm{q} \mathrm{ha}^{-1}\right)$ during the course of investigation. It might be due to the application of adequate amount of organic manures in combination with NPK. The reason for increasing fruit yield in cucumber was attributed to increased solubilization effect and availability of nutrients by the additions of organic manure and increased physiological activities leading to the buildup of sufficient food reserve for the developing sinks and better portioning towards the developing fruits. Besides, quick availability of plant nutrients from inorganic sources, balanced $\mathrm{C}$ : $\mathrm{N}$ ratio, enhanced the synthesis of photosynthates and production of auxin, amino acids and vitamins resulted in quantitative yield might be due to its additive effect on vegetative growth of the crop ultimately affecting the yield. Similar findings were also reported by Kanaujia et al., (2016), Baghel et al., (2017), Nagar et al., (2017) and Pradhan et al., (2018). 


\section{Quality parameters}

Quality parameters TSS ( ${ }^{0}$ Brix) and peel thickness $(\mathrm{cm})$ were significantly affected by various INM doses of organic manure and fertilizers during the crop growth period in cucumber as shown in (Table- 2). The maximum TSS of edible fruit $\left(4.11^{0}\right.$ Brix) and peel thickness $(1.33 \mathrm{~cm})$ were observed in $\mathrm{T}_{8^{-}}$ $75 \% \mathrm{RDF}+12.5 \% \mathrm{FYM}+12.5 \% \mathrm{VC} \mathrm{ha}^{-1}$ followed by $\mathrm{T}_{3^{-}} \mathrm{RDF}+10$ tones $\mathrm{VC} \mathrm{ha}{ }^{-1}$. However, the minimum TSS value (1.74 ${ }^{0}$ Brix $)$ and lowest peel thickness $(0.47 \mathrm{~cm})$ were recorded in control. The TSS of edible fruit $\left({ }^{0}\right.$ Brix) in cucumber was enhanced significantly due to application of inorganic fertilizer and organic manure in an integrated manner. It might be due to higher accumulation of carbohydrates, protein and captured energy by the abundant supply of nitrogen, phosphorous and potassium through mineral nutrient sources and organic sources of nutrients. This is in confirmation with findings of Kameswari et al., (2010), Aanjanappa et al., (2012) and Sharma et al., (2012).

On the basis of above findings it is concluded that the treatment $\mathrm{T}_{8^{-}}(75 \% \mathrm{RDF}+12.5 \%$ $\mathrm{FYM}+12.5 \% \mathrm{VC} \mathrm{ha}^{-1}$ ) was recorded the best among all the treatments combinations of organic and inorganic sources of nutrients in terms of growth and yield attributes and also increases the quality parameters like TSS and peel thickness. Therefore, it is suggested that a dose of $75 \% \mathrm{RDF}+12.5 \% \mathrm{FYM}+12.5 \%$ VC $\mathrm{ha}^{-1}$ suitable for the commercial cultivation of cucumber in western plain zone of Uttar Pradesh.

\section{References}

Anjanappa, M., Kumara, B. S. and Indiresh, K. M. (2012). Growth, yield and quality attributes of cucumber (cv. Hassan Local) as influenced by integrated nutrient management grown under protected conditions. Mysore Journal of Agriculture Science, 46 (1): 32-37.

Arisha, H. M. E., Gad, A. A. and Younes, S. E. (2003). Response of some pepper cultivars to organic and mineral nitrogen fertilizer under sandy soil conditions. Zagazig Journal of Agriculture Research, 30: 1875-99.

Arshad, I., Ali, W. and Khan, Z. A. (2014). Effect of different levels of NPK fertilizers on the growth and yield of greenhouse cucumber (Cucumissativus L.) By using drip irrigation technology. International Journal of Research, 1 (8): 650-60.

Arun, R and Kumar, R. J. (2014). Influence of nutrient management system on yield attributes of cucumber (Cucumis sativus L. var. Beit Alpha) cultivated in polyhouse conditions. Trends in Biosciences, 7(21): 3450-52.

Baghel, S. S., Bose, U. S. and Singh, S. S., (2017). Impact of Different Organic and Inorganic Fertilizers on Sustainable Production of Bottle Gourd [Lagenaria siceraria L.], Int. J. Pure App. Biosci. 5 (2): 1089-1094.

Das, R., Mandal, A. R., Priya, Anuj, Das, S. P. and Kabiraj, J. (2015). Evaluation of integrated nutrient management on the performance of bottle gourd [Lagenaria siceraria (Molina) Standl.]. Journal of Applied and Natural Science, 7 (1): 18-25.

De Candole, A. (1999). Origin of Cultivated Plants. Hafnar Publishing Co., New York, pp, 264.

Eifediyi, E. K., and Remison, S. U. (2010). Growth and yield of cucumber (Cucumis sativus L.) as influenced by farmyard manure and inorganic fertilizer. Journal of Plant Breeding and Crop Science, 2 (7): 216-220.

Ghasem, S., Morteza, A. S. and Maryam, T. 
(2014). Effect of organic fertilizers on cucumber (Cucumis sativus L.) yield. International Journal of Agriiculture and Crop Science, 7 (11): 808.

Gomez, A. K. and Gomez, A. A. (1996). Statistical procedure for Agriculture Research. John Willey and sons Pnc, New York.

Hazara, P., Chattopadhyay, A., Karmakar, K. Dutta, S. (2011). Cucurbits. Modern Technology in Vegetable Production. New India Publishing Agency, Pitam Pura, New Delhi-88, pp. 236-248.

Kameswari, P. L., Narayanamma, M., Ahmed, S. R., and Chaturvedi, A. (2010). Influence of integrated nutrient management in ridge gourd (Luffa acutangula (roxb.) L.). Vegetable Science, 37 (2): 203-04.

Kanaujia, S. P. and Daniel, M. L. (2016). Integrated Nutrient Management for quality production and economics of cucumber on acid alfisol of Nagaland. Annals of Plant and Soil Research, 18 (4): 375-380.

Kumar, S. and Karuppaiah, P. (2008). Effect of integrated nutrient management on growth and yield of Bitter gourd (Momordica charantia L.) type Mithipagal. Journal Plant Archives 8 (2): 867-868.

Mahmoud, E., EL- Kader, N. A., Robin, P., Akkal-Corfini, N. and El-Rahman, L.A. (2009). Effects of different organic and inorganic fertilizers on cucumber yield and some soil properties. World Journal of Agriculture Science, 5: 408-14.

Moharana, D. P., Mohan, L., Singh, B. K., Singh, A. K., Kumar, H. and Mahapatra, A. S., (2017). Effect of Integrated Nutrient Management on growth and yield attributes of Cucumber (Cucumis sativus L.) cv. Swarna Ageti under polyhouse conditions., The Bioscane, 12 (1): 305-
308.

Nagar, M., Soni, A. K. and Sarolia, D. K., (2017). Effect of Organic Manures and Different Levels of NPK on Growth and Yield of Bottle Gourd [Lagenaria siceraria (Mol.) Standl.]. Int. J. Curr. Microbiol. App. Sci, 6(5): 1776-1780.

Narayanamma, M., Chiranjeevis, C. H., Ahmed, R., and Chaturvedi, A. (2010). Influence of integrated nutrient management on the yield, nutrient status and quality of cucumber (Cucumis sativus L.). Vegetable Science, 37 (1): 61-63.

Pradhan, S. R., Sahu, G. S., Das, S., Sarkar, Tripathy, L. and Patnaik, A. (2018). Yield improvement in cucumber through Integrated Nutrient Management practices in coastal plain zone of Odisha, India. Int. J. Curr. Microbiol. App. Sci. 7(2): 2480-2488.

Prasad, P.H., Mandal, A. R, Sarkar, A., Thapa, U. and Maity, T. K. (2009). Effect of biofertilizers and nitrogen on growth and yield attributes of Bitter gourd (Momordica charantia L.). Proceedings, International Conference on Horticulture, pp 738-739.

Sareedha, P., Anburani, A. and Samruban, J. (2006). Influence of integrated nutrient management on growth of gherkin (Cucumis sativus L.) cv. Ajex Hybrid. Vegetable Science, 33: 196-97.

Sharma, J. P., Rattan, P. and Kumar, S. (2012). Response of vegetable crops to use of integrated nutrient management practices. Journal of Food and Agriculture Science, 2 (1): 15-19.

Shree, S., Regar, C. L., Ahmad, F., Singh, V. K., Kumari, R. and Kumari, A. (2018). Effect of Organic and Inorganic Fertilizers on growth, yield and quality attributes of hybrid bitter gourd (Momordica charantia L.) International Journal of Current 
Microbiology and Applied Sciences 7 (4): 2256-2266.

Singh, K. (1991). Role of nutrient elements and their hunger signs in vegetable crops. Manurial Requirements of Vegetable crops, pp, 4-5.

Singh, S. K., Yadava, R. B., Chaurasia, S. N. S., Prasad, R. N., Singh, R., Chaukhande, P. and Singh, B., (2016). Producing organic vegetables for better health. Indian Horticulture, 61 (1): 5-7.

Singh, V., Prasad, V. M., Kasera, S., Singh, B. P. and Mishra, S., (2017). Influence of different organic and inorganic fertilizer combinations on growth, yield and quality of cucumber (Cucumis sativus L.) under protected cultivation. Journal of Pharmacognosy and Phytochemistry, 6 (4): 1079-1082.

Thriveni, V., Mishra, H. N., Pattanayak, S. K., Sahoo, G. S. and Thomson, T.,
(2015). Effect of inorganic, organic fertilizers and bio-fertilizers on growth, flowering, yield and quality attributes of bitter gourd (Momordica charantia L.). International Journal of Farm Sciences, 5 (1): 24-29.

Vimala, P., Ting, C. C., Salbiah, H., Ibrahim, B. and Ismail, L., (1999). Biomass production and nutrient yields of four green manures and their effects on the yield of cucumber. Journal of Tropical Agriculture and Food Science, 27: 4755.

Vishwakarma, S. K., Gautam, D. S., Yadav, N. S., and Gautam, S. S. (2007). Effect of different levels of nitrogen and phosphorus on growth, yield and quality of spine gourd (Momordica dioica Roxb.). Technoframe-A Journal of Multidisciplinary Advance Research, 119-23.

\section{How to cite this article:}

Jagraj Singh, Manoj Kumar Singh, Mukesh Kumar, Archi Gupta and Kaushelendra Pratap Singh. 2020. Growth, Yield and Quality Parameters of Cucumber (Cucumis sativus L.) as Influenced by Integrated Nutrient Management Application. Int.J.Curr.Microbiol.App.Sci. 9(10): 1455-1462. doi: https://doi.org/10.20546/ijcmas.2020.910.173 